\title{
Presentasi Cerdas Menggunakan VIDEOSCRIBE
}

\author{
Liza Yulianti, M.Kom *1, Yupianti, M.Kom ${ }^{2}$, Reno Supardi, M.Kom ${ }^{3}$, Juju Jumadi, M.Kom \\ Abdussalam Al Akbar, M.Kom ${ }^{5}$ \\ ${ }^{1}$ Universitas Dehasen, Bengkulu, Indonesia \\ ${ }^{2,3}$ Fakultas Ilmu Komputer,Universitas Dehasen Bengkulu, Bengkulu, Indonesia
}

Email:**liza.yulianti@unived.ac.id

\begin{abstract}
ABSTRAK
Pemanfaatan media teknologi aplikasi Videoscribe tidak hanya digunakan dalam proses pembelajaran pada universitas saja tetapi dalam proses pembelajaran di sekolah juga bisa di terapkan untuk membuat presentasi yang unik, inovatif, dan menumbuhkan kreativitas para siswa siswi yang secara langsung dapat di kreasikan ke dalam bentuk video animasi dimana banyak pengguna aplikasi ini yang memanfaatkan untuk menyampaikan sebagai media komunikasi, dari pemberi informasi ke penerima informasi. Sebagai pemberdayaan para siswa siswi maka kami berupaya memberikan solusi untuk memperkuat potensi atau daya yang dimiliki oleh para siswa dan siswi untuk menjadi semakin berdaya, kreatif, dan inovatif yang tidak saja mengenal pembuatan presentasi hanya bisa melalui microsoft powerpoint saja tetapi juga bisa dengan bantuan Videoscribe yang menyediakan banyak animasi yang dapat dikembangkan dan diaplikasikan sesuai dengan ideide yang dimiliki. Hasil dari sosialisasi ini adalah menambah wawasan peserta dengan menggunakan komputer yang didukung oleh jaringan internet maupun mode offline dimana aplikasi VideoScribe dapat dimanfaatkan sebagai media pembuatan presentasi berbasis video animasi.
\end{abstract}

Keywords: Presentasi, VideoScribe, Animasi

\section{PENDAHULUAN}

Pendidikan merupakan pembentukan awal karakter manusia, dan membangun karakter yang terdidik harus di lakukan dengan beragam cara-cara yang tepat. Pada zaman Teknologi Informasi sekarang ini telah berkembang pesat akses internet baik dalam bidang Pendidikan, dimana Pendidikan saat ini cenderung memanfaatkan Teknologi Informasi dan jaringan contohnya dalam proses belajar mengajar, baik untuk guru maupun siswa.

Dalam Pendidikan skala sekolah banyak masalah - masalah yang dapat diselesaikan dengan menggunakan komputer dan jaringan internet. Masalah tersebut dapat timbul baik dari guru maupun siswa maupun pegawai yang ada di sekolah itu sendiri. Contoh pembelajaran yang masih bersifat tradisional dan kurang intreraksi dengan sekolah - sekolah lain karena keterbatasan jarak serta kurangnya worskshop tentang cara pengajaran yang baik bagi guru. Presentasi Cerdas Menggunakan Videoscribe, Videoscribe biasa digunakan untuk pendidik atau Guru atau Dosen sebagai pengantar pembelajaran yang biasa digunakan sebagai bahan presentasi, memberikan pengetahuan kepada siswa dan guru tentang bagaimana cara membuat dan membangun sumber atau media mengajar yang baik bagi guru.

Dengan diterapkannya Presentasi Cerdas Menggunakan Videoscribe dapat memenuhi aktifitas sekolah dan akan bermanfaat terlebih jika system Videoscribe ini mempunyai kehandalan kemampuan berpikir dan mengkombinasikannya melewati video animasi. 


\section{METODE}

Adapun Metode Kegiatan yang digunakan dalam Kegiatan Pengabdian Pada Masyarakat Dosen ini adalah sebagai berikut :

1. Ceramah tentang bagaimana membuat "Presentasi Cerdas Menggunakan Videoscribe" untuk para siswa siswi kelas X SMA Negeri 4 Pagarjati Bengkulu Tengah, dimana penyaji yang terdiri dari 5 orang akan secara bergiliran untuk memberikan materi.

2. Sosialisasi dan praktek penggunaan Aplikasi atau software yang digunakan dalam mendukung atau dalam membuat menggunakan animasi yang berupa video.

\section{HASIL DAN PEMBAHASAN}

\section{A. Evaluasi Keberhasilan}

Keberhasilan dari kegiatan ini tidak terlepas dari adanya faktor pendorong dan faktor penghambat, dimana yang dirasakan sebagai faktor penghambat antara lain yaitu waktu yang harus disesuaikan dengan para siswa yang bersangkutan agar tidak mengganggu jam pelajaran para siswa tersebut. Hal ini dapat diatasi dengan adanya kerjasama yang baik antara semua pihak yang terlibat. Sedangkan faktor pendorong disini, adanya penerimaan yang ramah dan tangan terbuka dari pihak sekolah serta bagaimana para siswa siswi dengan semangat yang tinggi dalam mendengarkan semua materi yang diberikan. Oleh sebab itu, dengan adanya kegiatan Pengabdian Pada Masyarakat ini, merupakan salah satu bentuk kegiatan yang sangat mendukung program pemerintah dalam upaya meningkatkan kualitas pendidikan/pengajaran, dan telah memberikan bekal pengetahuan kepada peserta guna mendukung media teknologi informasi yang telah berkembang dengan pesat saat ini.

\section{B. Alasan Kelanjutan Kegiatan}

Selama pelaksanaan program sosialisasi ini, mulai dari tahap persiapan sampai pelaksanaannya, dapat kami sampaikan temuan-temuan sebagaiberikut :

1. Antusias peserta pelatihan sangat tinggi, menyambut dengan baik tawaran kerjasama sebagai mitra dalam program pengabdian masyarakat ini. Pihak sekolah berharap program ini bisa dilaksanakan secara regular dan berkala di tahun-tahun selanjutnya.

2. Materi sosialisasi yang diberikan sangat sesuai dengan level pembelajaran untuk siswa dan guru SMA Negeri 4 Pagar Jati Bengkulu Tengah. Materi ini benar-benar memberikan penyegaran dan penambahan wawasan atas program-program aplikasi di luar yang telah mereka dapatkan di sekolah.

\section{KESIMPULAN DAN SARAN}

A. Kesimpulan

Berdasarkan hasil kegiatan yang telah dilaksanakan dalam rangka pengabdian pada masyarakat bagi dosen, maka analisa dan evaluasi yang dapat disimpulkan adalah sebagai berikut :

1. Materi yang telah diberikan pada siswa siswi SMA Negeri 4 Pagarjati Kabupaten Bengkulu Tengah, berguna sebagai bahan tambahan pembelajaran bagi mereka diluar mata pelajaran inti, untuk menunjang dalam bidang lain dengan mengikuti perkembangan Ilmu Pengetahuan dan Teknologi.

2. Semua siswa dan siswi sangat antusias dalam menerima mendengar dan memperhatikan dengan seksama dari awal sampai akhir kegiatan yang mana dapat meningkatkan wawasan mereka dalam bidang IT. 


\section{Urnal PADAMU NEGERI}

(Community Service in the Field of Science, Technology, and Agricultural)

Available online at : http://journal.pdmbengkulu.org/index.php/padamunegeri

DOI: DOI: https://doi.org/10.37638/PadamuNegeri.1.1.18-20

B. Saran

Peningkatan dalam sarana perangkat komputer bagi para siswa, guna mendukung dalam proses belajar mengajar para siswa siswi dan perlunya diadakan kegiatan lanjutan dengan topic atau materi yang berbeda.

\section{DAFTAR PUSTAKA}

Kustian, dkk. (2019). SOSIALISASI PEMANFAATAN APLIKASI SPARKOL VIDEOSCRIBE DALAM PEMBUATAN BAHAN PRESENTASI PADA KARANG TARUNA, Jurnal $P K M, 2$ (1). DOI: 10.30998/jurnalpkm.v2i01.2987

Putra, D.E. 2012. Teknologi Informasi dan Komunikasi. http://endra-dwiputra.blogspot.co.id 